\title{
TUMOR SURGERY WITHIN CEREBRAL ELOQUENT AREAS: A TWO-INSTITUTIONS EXPERIENCE
}

\author{
Signorelli Francesco, ${ }^{1,3}$ Maduri Rodolfo, ${ }^{4}$ Chirchiglia Domenico, ${ }^{2}$ Guyotat Jacques ${ }^{3}$ \\ ${ }^{1}$ Department of Experimental and Clinical Medicine, ,Magna GrFcia“ University, Catanzaro, Italy \\ ${ }^{2}$ Department of Medical and Surgical Sciences, ,Magna GrFcia“ University, Catanzaro, Italy \\ ${ }^{3}$ Hospices Civils de Lyon, Service de Neurochirurgie D, \\ Hôpital Neurologique et Neurochirurgical Pierre Wertheimer, Lyon, France \\ ${ }^{4}$ Centre Hospitalier Universitaire Vaudois, Service de Neurochirurgie, Lausanne, Switzerland
}

Primljen/Received 29. 06. 2014. god.

Abstract: Introduction: Tumor surgery within eloquent areas represents a formidable challenge and the use of electrical cortico-subcortical stimulation mapping (ESM), allows to localize sensorimotor and language areas and pathways. Our aim is to point out methodological issues of ESM and its impact on outcome at the light of a prospective analysis of a two-institution series of 159 patients with lesions involving eloquent areas with a lengthy follow up.

Material and Methods: All patients operated on for lesions involving eloquent areas between May 2000 and May 2010 at the Neurosurgical Department of the Neurological and Neurosurgical Hospital "P. Wertheimer" in Lyon (France) and at the Neurosurgical Departement of the University Hospital in Catanzaro (Italy), were enrolled prospectively in our study.

Results: Of 159 consecutive patients, 141 of them underwent surgical removal of the lesion with the aid of electrical cortico-subcortical stimulation mapping integrated in a setting of intraoperative localization of anatomic landmarks for eloquent areas.

For the remaining 18 patients ESM was not deemed useful or feasible: 15 patients received a biopsy and 3 patients received tumor debulking under general anesthesia.

For patients operated with ESM, it was possible to achieve a gross total removal of the lesion in $67,4 \%$ of cases ( 95 patients). One patient died in the immediate postoperative period for a pulmonary embolism. At a total mean follow-up of 62.8 months 78 patients were alive, 62 of which were recurrence free and had a KPS of $70 \%$ or more, while the other 80 patients had a mean survival time of 23.9 months, with a mean high quality survival period (KPS $\geq 70$ ) of 21.6 months.
Prihvaćen/Accepted 15. 07. 2014. god.

Discussion and Conclusion: Intraoperative electrical language and motor mapping, when feasible and indicated, consistently localizes eloquent cortical areas and subcortical pathways and allows to set the tumor resection boundaries according to functional limits, with a favorable impact on survival and quality of life. Integration of neurofunctional data with anatomic landmarks is nonetheless useful to expedite the surgical procedure and improve specificity and sensibility of functional mapping.

Key words: electrical stimulation mapping, functional mapping, awake surgery, eloquent areas, supratentorial tumors, gliomas, extent of resection.

\section{INTRODUCTION}

Pre-operative assessment of safe tumor removal for lesions deemed to involve eloquent areas on the basis of pure anatomic criteria is frequently imprecise (1) and may lead to reject surgery or to undue incomplete tumor resections. As a matter of fact, true infiltration of cortical sensorimotor and language areas is not a frequent finding (2). Two factors concur in determining this situation: the cerebral plasticity, which induces a functional reshaping within the infiltrated brain, and the extreme individual variability of location of functional areas $(3,4)$. Pre- and intraoperative brain mapping techniques have been developed in order to locating and thus preserving functional tissue during surgery in eloquent areas. Intraoperative methods have the advantage to reproduce more precisely the spatial distribution of functional circuits along with their temporal variation in response to the presence as well as the removal of the lesion (5-8). Here we report our experience of 
application of intraoperative cortical and subcortical mapping by direct ESM during surgery of a wide variety of lesions involving sensorimotor and language areas, with emphasis on the technique, its applications and usefulness.

\section{MATERIAL AND METHODS}

All patients operated on for lesions in sensorimotor and language areas between May 2000 and May 2010 at the Neurosurgical Departments of Lyon, France and Catanzaro, Italy, were enrolled in the study. Preoperative and immediate postoperative clinical and radiological data were collected prospectively. Clinical and radiological postoperative follow-up was done at 3,6 , and 12 months and yearly or at aggravation thereafter. Hemispheric dominance was determined by the Edinburgh Handedness Inventory Test and, in cases of ambiguous language lateralization, by functional magnetic resonance imaging (fMRI) (9). Clinical evaluation included baseline and postoperative 3 and 6 month and yearly neuropsychological assessment (Montreal-Toulouse protocol, MT-86, and Boston Diagnostic Aphasia Examination) for patients harboring cerebral tumors located in an area expected to be involved in speech. The extent of surgical removal was appreciated on a T1 contrast - enhanced MRI for HGG or T2 MRI for LGG, performed in 50 cases within 2 postoperative days and in all cases 2 to 3 months after surgery. A complete removal was defined as no tumor residue, while for subtotal or partial removal the residual tumor volume was respectively higher or lower than $10 \mathrm{cc}$. The adjuvant treatment for gliomas as well as for metastasis was quite homogeneously administered: all HGG had postoperative radiotherapy and chemotherapy (Temozolomide or PVC), while LGG underwent radiotherapy only at recurrence. Patients with metastasis were treated with postoperative whole brain radiotherapy or focal beam radiotherapy and chemotherapy.

At the admission careful explanation of the purpose, modalities and risks of the procedure was given to the patients and/or their tutors. Written informed consent was obtained from all patients participating to the study or patients' tutors.

\section{Technique of Electrical Stimulation Mapping (Figure 1 and 2)}

Language mapping was undertaken while patients were awake after having anesthetized the scalp and temporal muscle by a mixture of $2 \%$ lidocaVne and $0.25 \%$ marcaVne. During realization of the craniotomy a mild intravenous sedation (propofol) and analgesia (alfentanyl or remifentanyl) was administered to the patients and was discontinued during language mapping. For motor mapping in the non-dominant hemisphere patients underwent surgery after induction of general anesthesia. Short acting relaxants and propofol were used but not curarisation neither barbiturates nor volatile anesthetic agents (halothane, enflurane and isoflurane), which decrease in a dose-dependent manner the cortical excitability to electrical stimulation (10). A constant current stimulator (Ojemann, OCSI, Radionics, USA and Nimbus cortical stimulator, Newmedic, Toulouse, France) delivered biphasic square-wave electrical stimulations through a bipolar silver ball electrode with the extremities $5 \mathrm{~mm}$ apart. The current parameters were fixed as follows: duration 1

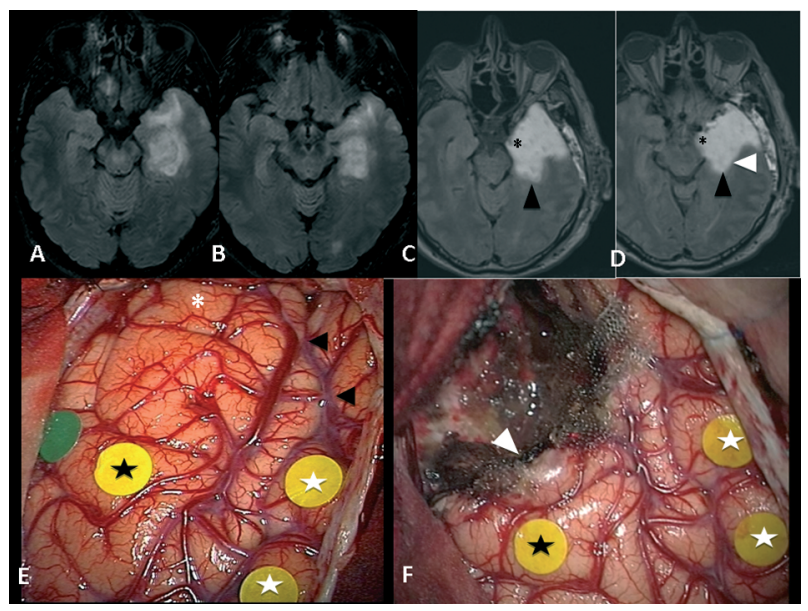

Figure 1 A, B: FLAIR 3D MPRAGE MRI of a 48 y.o. man presenting with partial dominant temporal lobe seizures. MRI shows a low grade glioma infiltrating the left temporal lobe extending to the mesial temporal structures. C, D: Postoperative FLAIR 3D MPRAGE $M R I$ shows supra-total removal of the lesion, extended to the uncus (black asterisk) and parahyppocampal gyrus (black arrowhead). White arrowhead shows the posterolateral limit of the resection at the lateral edge of the temporal horn of the lateral ventricle, whose stimulation triggered anomia. $\boldsymbol{E}$ : intraoperative picture showing the exposure of the left temporal lobe from the pole (white asterisk) up to the the middle temporal lobe. Yellow tags show cortical language sites on the superior (white stars) and middle (black stars) temporal gyrus, whose direct electrical stimulation triggered semantic paraphasias. Green tag is on the inferior temporal gyrus, where direct electrical stimulation triggered anomia. Black arrowheads shows the horizontal segment of the sylvian fissure. $\boldsymbol{F}$ : Intraoperative picture showing the resection cavity, which respects the cortical language sites. White arrowhead indicates the subcortical white matter of the arcuate fasciculus and corresponds to the site on Fig. 1 D, whose stimulation triggered anomia. 


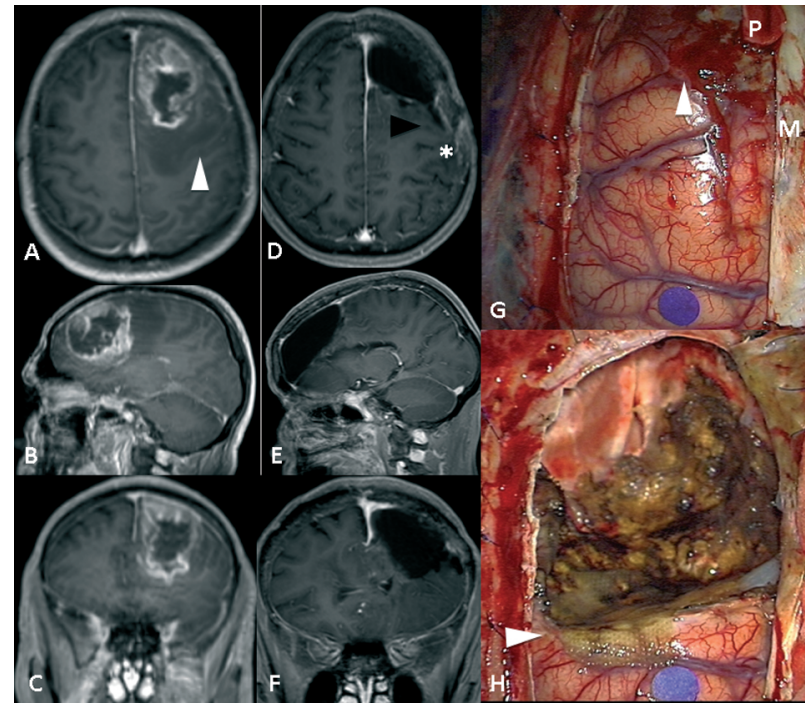

Figure 2 A, B, C: Preoperative T1-weighted gadolinium enhanced MRI of a 58 y.o. man with a left temporal lobe glioblastoma. The lesion displaces posteriorly the central sulcus (white arrowhead). D, E, F : Postoperative T1-weighted gadolinium enhanced MRI shows a gross total removal and no contrast enhancement. The surgical cavity is flush with the precentral sulcus laterally (black arrowhead). The primary motor area on the central gyrus is respected (white asterisk), which corresponds to the electrical stimulation mapping finding. $\boldsymbol{G}$ : intraoperative picture, showing an hemorrhagic lesion infiltrating the left premotor cortex (white arrowhead) and extending into the subcortical white matter posteriorly. The blue tag corresponds to the primary motor area, whose electrical stimulation triggered the flexion of the right forearm, $H$ : intraoperative picture, showing the resection cavity, that respects the primary motor area and goes flush with the precentral sulcus laterally (withe arrowhead). $M$ indicates the midline, $P$ is the frontal pole.

msec single-phase; pulse frequency of $60 \mathrm{~Hz}$; amplitude from 1 to $10 \mathrm{~mA}$. Stimulation was initiated at the central gyrus with a low current $(1 \mathrm{~mA})$ and was increased of $0.5 \mathrm{~mA}$ to $1 \mathrm{~mA}$ until the effective current threshold, sufficient to induce clinically evident involuntary movements of a restricted body part (face, fingers, hand, forearm, tight, leg or foot), was reached. The same current threshold was used for language and sensory mapping. EcoG was always in use during language mapping and in the first 10 cases of motor mapping in general anesthesia. The purpose of its use was to establish the highest current intensity that did not trigger after-discharges, which are expression of current spread. Language testing encompassed systematically counting (from 1 to 10 and back) when stimulating frontoparietal perisylvian and premotor/supplementary motor areas. These areas where stimulated first, in order to identify sites of speech arrest/anarthria. The DO 80 test was used for deno- mination by asking the patient to name 80 drawn pictures selected accordingly to demographic variables such as level of education, age and sex. We also added a sentence reading task when testing posterior temporal and parietal areas. All stimulated cortical sites were labeled by sterile tags, colored or marked differently to distinguish the sites for whom ESM caused speech disturbance (speech arrest/anarthria, anomia, paraphasias, perseverations, comprehension troubles) (Fig. 1), motor (muscle contractions) (Fig. 2) or sensory (dysaesthesias) response or no response at all. Subcortical stimulation, which was alternated with tumor resection, was then performed at intensity 1 to $2 \mathrm{~mA}$ higher than the one effective to elicit muscle contraction or speech troubles on the cortex. The use of high stimulation intensities is safer subcortically than on the cortex, as there are no risks of provoking intraoperative seizures while stimulating white matter (11-13).

Patients presenting preoperatively with a severe deficit had intraoperative electromyography using a three to eight channels Key Point electromyographer (Ebneuro Italia) with a band pass of 29 to $1000 \mathrm{~Hz}$ and a display gain of $200 \mathrm{~V} /$ division (14). Stimulation was applied randomly to the cortex near or overlying the lesion, to the brain parenchyma infiltrated by the tumor and to the cortical sites likely to be involved in sensorimotor or language function, avoiding to stimulate consecutively cortical sites distant less than 2 centimeters (cm), so as to elude the latency effect.

\section{Analysis parameters and Statistics}

Survival was calculated as the time interval in months from the surgical intervention to death or the date of the last follow-up. Survival curves were constructed using the method of Kaplan and Meier. Age at diagnosis and preoperative KPS score, as well as the World Heal Organisation (WHO) grade and the extent of surgical resection were analyzed for their impact on survival using a multivariate analysis model of logistic regression with backward elimination. Statistical analysis was performed using (PASW Statistics 18) (SPSS Inc., Chicago, IL, USA). A p value $<0.05$ was considered to be statistically significant. We also calculated the relative risk of survival at 4 years for LGG and at 1 year for HGG, stratifying it according to the extent of removal. ESM was not considered as a potential prognostic factor. The reason was that the patients that did not undergo ESM were a highly selected population.

\section{RESULTS}

One hundred fifty nine consecutive patients harboring a lesion located in or near sensorimotor and/or language areas referred to both Neurosurgical Depart- 
ments in Lyon, France, and Catanzaro, Italy, between May 2000 and May 2010 were prospectively enrolled in the study. There were 73 women and 86 men, aged 18 to 81 years, with a mean age of 58 years. Sixty-six patients harbored a lesion located in the dominant hemisphere in or next to language areas, while 93 patients had lesions close to or infiltrating sensorimotor pathways of the non-dominant hemisphere. One hundred eleven $(69.8 \%)$ patients presented with partial or secondarily generalized seizures. Clinical onset was marked in 38 patients by language troubles, which were regressive in the majority of cases (24 out of 38). 6 patients did not undergo awake craniotomy because they exhibited significant phasic troubles, which would have hindered intraoperative language testing. The other 8 patients, presenting with minor speech difficulties at surgical intervention, were nonetheless able to undergo intraoperative questioning according to preoperative language evaluation. Other presenting symptoms were motor deficits (83 patients), that were severe (no active movements against resistance) in 29 (36.1\%), sensory deficits (20 patients), mild (41 patients) to severe (3 patients) intracranial hypertension, mnemonic troubles (11 patients), behavioral changes (12 patients), astereognosia (4 patients). Preoperatively, 52 patients with intracerebral tumors located in an area expected to be involved in speech were submitted to neuropsychological evaluation (Montreal-Toulouse protocol and Boston Diagnostic Aphasia Examination) to provide an exhaustive assessment of language functions. The patients' preoperative status was determined according to KPS and was high (75.8\%) in average, even if there were 40 patients with a KPS $<70$. All patients underwent gadolinium-enhanced MRI using a 1.5 Tesla MR scanner (Magnetom Impact Expert, Siemens, Erlangen, Germany). One hundred forty one patients underwent surgical removal of the lesion while using cortico-subcortical ESM of language and sensory-motor functions while awake (50 patients) or ESM of motor pathways in general anesthesia (91 patients). Of the 18 patients operated on without the support of ESM, 2 patients with dominant temporal lobe lesions had to be intubated due to severe agitation before the completion of functional cartography and underwent an open biopsy. Thirteen other patients underwent a stereotactic biopsy and not a surgical removal for the following reasons: severe aphasia (6 patients), bilateral frontal lobe and corpus callosum infiltration of a HGG (3 patients), basal ganglia and brain stem infiltration (2 patients), gliomatosis cerebri (1 patient) and refusal of awake surgery ( 1 patient). The three remaining patients underĐpard -went an emergent tumor debulking for impending temporal lobe herniation due to a HGG infiltrating left temporal lobe. The same current threshold was effective in disrupting language (eliciting speech arrest/anarthria, anomia, paraphasias, perseveration, lack of understanding) and triggering segmental movements and dysaesthesias in most of our patients. ECoG, used during language mapping in the first 10 cases of motor mapping under general anesthesia, never detected a spread of current to cortical areas remote from the stimulated site when the current intensity did not exceed the threshold triggering motor responses (between 1.5 and $5 \mathrm{~mA}$ ). Nonetheless, we found ECoG useful when electrical stimulation for language mapping of dominant perisylvian or dorsomedial prefrontal cortex was negative at the same intensity educing motor responses. For these patients, 10 out of the 50 operated while awake for lesions in speech areas, language was tested while stimulating cortex at current amplitude set 0.5 to $1 \mathrm{~mA}$ lower than the one triggering after discharges. For all these 10 patients language was disrupted using a current intensity 1 to $3 \mathrm{~mA}$ higher than that educing muscle twitches. Twenty-one patients out of thirty presenting preoperatively with a severe deficit had intraoperative electromyography using a three to eight channels Key Point electromyographer (Ebneuro Italia) with a band-pass of 29 to 1000 Hertz and a display gain of $200 \mathrm{~V} /$ division (14).

For all 50 patients operated on while awake it was possible to identify at least one ESM positive language site. Cortical ESM identified motor strip in 112 out of 119 patients $(94.1 \%)$ for whom it was used and, notably, in 25 out of 29 patients presenting with severe motor deficits. Besides these 5 severely paretic patients, ESM failed to evoke motor responses also in two cases of post-central low grade tumors, in which motor strip was not included into the craniotomy. As a matter of fact, these two patients did not show any new deficit postoperatively. Subcortical ESM was applied in 99 patients for locating motor pathways, as we did not employ this procedure when the lesion boundaries were not flush with the primary motor area or anatomically distant from internal capsule, as seen in twenty patients. In six patients ESM was not useful, 5 of them were severely paretic preoperatively and one was aggravated by the surgical violation of subcortical pyramidal pathways in corona radiate. We employed systematically subcortical language mapping in the last 29 patients operated on awake, while for the first 20 patients of our series we always respected a security limit of 1 $\mathrm{cm}$ from the eloquent cortex. Nonetheless, 3 out of these had a postoperative permanent phasic impairment, due to interruption of subcortical language pathways, as shown on postoperative MRI. Intraoperative seizures occurred in 15 patients, even if cautious stimulation using low current thresholds (between 1.5 and $7 \mathrm{~mA}$ ) was used in these cases, with no postoperative conse- 
quences. For the 141 patients operated on using intraoperative ESM, a macroscopically complete removal of the tumor was carried out in 95 cases $(67.4 \%)$, while in the other 46 cases tumor invasion of functional cortex and subcortical functional pathways limited resection. For what concerns the $18 \mathrm{HGG}$ patients operated on without ESM, no total removal was carried out but 15 biopsies and 3 partial removals. Histopathological findings graded according to the WHO central bnervous system tumors classification (15)were as follows: 28 low grade astrocytomas, 10 low grade mixed gliomas, 16 low grade and 20 anaplastic oligodendrogliomas, 1 gliosarcoma, 13 metastasis, 5 pylocitic astrocytomas, one recurrent ependymoma, 35 glioblastomas, 13 anaplastic astrocytomas, 2 dysembrioplastic neuroepithelial tumor, 4 meningiomas, 4 arterovenous malformations and 7 cavernomas. One patient died in the immediate postoperative period for a pulmonary embolism and was excluded from the study as concerns survival. Immediate postoperative neurological aggravation occurred in 93 out of 141 cases operated on with ESM (66 $\%$ ). Troubles were completely regressive within 4 weeks in 75 patients, while 10 patients recovered completely by the $3^{\text {rd }}$ postoperative month and 11 patients $(7.8 \%)$ where definitively aggravated in comparison to the preoperative period. Causes of definitive aggravation were the development of a postoperative hematoma in 3 patients, cortico-subcortical infarction due to damage of MCA branches in 4 patients and infringement of subcortical functional pathways, as detailed above, in 4 patients. Neurological improvement, for example improvement of at least 1 grade of the Oxford 5 ranks motor scale, took place between 1 week and 6 months after intervention for 50 out of 83 patients presenting preoperatively with a paresis $(60.2 \%)$, and in 14 out of 29 severely disabled patients, while also 12 of 20 patients presenting with sensory troubles improved postoperatively. Moreover, speech troubles improved in 5 out of 14 preoperatively aphasic patients. Postoperative improvement of motor and phasic deficits regarded exclusively patients operated on with the aid of ESM. All surviving patients had a minimum follow-up of 4 years. No patient was lost at follow-up. At a total mean follow-up of 62.8 months 78 patients were alive, 62 of which were recurrence free and had a KPS of $70 \%$ or more. Eighty patients died and had a mean survival time of 23.9 months, with a mean high quality survival period (KPS $\geq 70$ ) of 21.6 months. Stratifying the outcome according to histology and tumor grading, 47 out of 54 LGG patients were still alive at the last check-up, with a mean survival period of 80.5 months (52-120 months). The rate of complete resection for LGG was $40.7 \%$ and none of the 22 LGG patients with a complete removal displays a recurrence to date.
Twenty patients had a KPS of 70 or more, while 2 patients, operated on at the beginning of our experience, developed hemiparesis due to the surgical lesion of subcortical pathways and to a postoperative middle cerebral artery infarction respectively. Among 32 LGG patients that underwent subtotal or partial removal, 7 died, 5 with a partial removal and 2 with a subtotal removal, and had a mean survival of 39.6 months with a high quality survival period of 35.8 months. Among them there were 3 patients whose speech function was impaired by a surgical interruption of subcortical pathways. The other $25 \mathrm{LGG}$ patients were alive at a mean follow-up of 78.7 months and 15 of them were autonomous. It is worth nothing that all LGG patients had a minimum follow-up period of 4 years. At this end-point the extent of resection significantly correlates with survival $(p<0.05)$ : all 22 patients that underwent GTR of the lesion survived ( $100 \%$ survival rate at 4 years), while survival rates at 4 years for subtotal removals and partial removals were respectively $90.5 \%$ and $54.5 \%$. The relative risk of survival at 4 years for patients with GTR was 1.1 if compared with SR, 1.83 if compared with PR and 1.28 if compared with both. For what concerns $\mathrm{HGG}$, total resection rate $(74.5 \%)$ is higher compared to LGG because tumor infiltration of eloquent sites was a more rare finding. In our series there are 5 long survivors, with a mean survival period of 67.2 months (64-72 months). One was an anaplastic astrocytoma and 4 were high-grade oligodendrogliomas and all benefited of a GTR according to functional limits as located by intraoperative ESM. Three patients showed recurrence in the follow-up period, which determined a neurological impairment with loss of autonomy (KPS $<70 \%$ ). The other 46 patients treated with the aid of ESM had a mean survival of 15.7 months (0-29 months), with a high quality survival period of 14.1 months. Also survival of HGG patients was significantly correlated with extent of resection at 1,2 and 4 years $(p<0.05)$ : rate of survival at 1,2 and 4 years for total removals were respectively $94.7 \%, 21.0 \%$ and $13.1 \%$, while for subtotal removals survival rate was $75 \%$ and $0 \%$ at 1 and 2 years respectively, and no patients that underwent partial removal survived at 1 year. The 18 patients with HGG operated on without ESM, all deceased, had a mean survival of 6.2 months. The relative risk of survival at 1 year for $\mathrm{HGG}$ patients with TR was 1.26 if compared with SR. Among the 13 patients operated on for a metastasis, there were 3 long survivors with a mean follow-up of 67.3 months and one displayed an extra-cerebral tumor relapse. The other 10 patients with cerebral metastasis had a mean survival of 34.2 months (21-44 months). All the other 23 patients operated on for benign tumors or vascular malformations were alive at a mean follow-up of 84.9 
months (57-120 months) and were autonomous without recurrence of the previously resected lesion. All survivors were seizure-free. Twenty-nine of 111 patients presenting preoperatively with seizures discontinued their antiepileptic drugs. They were all 7 patients with cavernomas, 3 out of 4 patients operated on for an arterovenous malformation, one primitive neuroectodermal tumor and all pylocitic patients, 3 out of 4 meningioma patients and $10 \mathrm{LGG}$ patients. Fifteen other patients, one arterovenous malformation, one primitive neuroectodermal tumor and 13 LGG, had their treatment tapered.

\section{DISCUSSION}

Many authors advocate aggressive surgical resection of intrinsic brain tumors to lengthen survival and preserve quality of life of patients (16-20). Yet, resection of intracranial lesions in or close to sensorimotor and language areas remains a technical challenge and carries risks of postoperative aggravation even though nowadays pre- $(6,21,22)$ and intraoperative functional mapping techniques, that allow to locate and respect eloquent sites, concur in lowering these risks $(6,5,8$, 11, 20-22). Eloquent sites display a great individual variability of location and organization and the distortion of normal cerebral topography engendered by mass effect further reduces the reliability of anatomical landmarks. Currently, the gold standard for locating cortico-subcortically sensorimotor and language functions is represented by intraoperative $\operatorname{ESM}(5,11,20)$. The application of intraoperative cortico-subcortical ESM allows conducting the resection according to functional limits, thus optimizing the quality of removal for slowly growing lesions as well as high-grade tumors (23-30), all the while preserving the quality of life of patients. Our experience about the application of intraoperative cortico-subcortical ESM provides a follow-up lengthy enough to evaluate the impact of the technique on the survival curve and quality of life of a series of patients operated on for a wide variety of intracranial lesions involving sensorimotor and language areas. In our hands the rate of macroscopically complete tumor resection, $67.4 \%$ overall, favorably compares with the one of other surgical series dealing with gliomas infiltrating non eloquent areas $(31,32)$ as well as with other authors' series employing ESM as the fundamental tool for locating functional tissue $(20,26)$. Actually, white matter stimulation allowed us to locate and respect subcortical language and sensorimotor pathways and consented to push surgical resection flush with cortical eloquent sites and perform a resection according to functional limits, removing all infiltrated tissue around the lesion not storing eloquent sites (11,
33). As a matter of fact, the introduction of continuing subcortical language mapping for the 29 most recent awake craniotomy cases of our series represented a major improvement in our technique, compared to the 20 first cases for whom no systematic subcortical mapping was used, in terms of both total tumor resection rate (20 cases, $66.7 \%$ and 11 cases, $55 \%$, respectively) and permanent post-surgical phasic impairment ( 2 cases, $6.7 \%$, and 4 cases, $20 \%$, respectively). Thus, this technical breakthrough correlates with an optimization of removal of non functional infiltrated tissue and a reduced risk of postoperative permanent phasic impairment and introduces a new principle in glioma surgery, according to whom the resection limits, pushed up to the very limit of eloquent areas, are anatomic as well as functional. We found total tumor resection to be a statistically significant predictor of either 4-year-survival in LGG and 1 year-survival in HGG, in accordance with other author's data $(18,23)$, with no recurrence for LGG that were completely resected. The theoretical explanations of the correlation of a better outcome with a complete resection in case of LGG are as plausible as difficult to prove. The reduction of the mass effect is not likely to have an immediate postoperative clinical impact, as it is rare that LGG present with intracranial hypertension, unlike HGG. Nonetheless, reducing the contingent of tumor cells at sea of malignant transformation and infiltration of primary eloquent areas could display a beneficial effect at a distance. However, even if the precise clinical impact of radical removal of a LGG can be judged only in the long run, there are arguments in favor of an early resection, at diagnosis, since small preoperative tumor volumes $(<10$ $\mathrm{cc})$, correlate with a lower risk of recurrence (25). Another reason for an early resection in LGG patients is a better control of epilepsy if the history of seizures is shorter $(28,29)$. This has a positive impact on the quality of life of patients, as shown in our series, where 44 out of 77 patients presenting with seizures from a lesion other than a HGG had their treatment discontinued or tapered. It is important to note that, there was a higher resection rate for HGG, compared to LGG, respectively $74.5 \%$ and $40.7 \%$, which is in accordance with other authors' data (20). The explanation must be sought in the fact that LGG are more infiltrative in nature than malignant gliomas. The latter displace more than infiltrate functional nervous tissue and, due to their higher growth rate, would induce a limited peritumoral functional reorganization, which correlates with the fact that HGG present more frequently with preoperative deficits than LGG. ESM proved its usefulness also when dealing with lesions presenting generally with more a clear separation from normal brain compared to intrinsic tumors, such as metastasis (13), meningioma 
and vascular malformations $(31,32)$. In our series we chose to employ ESM when these lesions were subcortically located or had very poor borders from surrounding nervous tissue, with a total resection rate of $100 \%$ and no permanent postoperative aggravation.

Nevertheless, intraoperative ESM is a procedure with a steep learning curve, if we consider that not all teams using it confirmed its utility and advantages. Its reliability depends on a number of factors, which are operator-related as well as patient-related. In fact, the sensitivity and specificity of the functional mapping relies much on the correct clinical indication: patients that are not able to cope with the procedure, with severe, long established deficit or impending temporal lobe herniation should be excluded, as we did for 18 cases in our series. Moreover, a strict protocol has to be employed, that should be as more standardized as possible, to reduce the false positives and negatives and expedite the procedure. The effective current threshold should be fixed, that depolarizes the area in contact with the stimulating electrodes without a spread of its effect. Intraoperative ECoG rules out the dispersal of electricity detecting after discharges $(11,20)$, but its utility is higher while performing cortical stimulation during language mapping $(19,6)$. Conversely, ECoG is not necessary while mapping motor cortex, since its depolarization is obtained with lower current intensities than language areas and current diffusion is less frequent. An effort of shortening the intraoperative procedure is warranted by the necessity of reducing artifacts due to patients' fatigue thus reducing perioperative discomfort. Actually, functional stimulation mapping has its own limits and drawbacks: its reliability is not absolute if $2.5 \%$ of Taylor's series presented a permanent worsening even if ESM was negative and it can be prejudiced by the patient's fatigue when realized in local anesthesia (34). The presence of preoperative language and sensorimotor deficits not recently started may represent another cause of false negatives, while in very young patients incomplete myelination of motor pathways may preclude their identification by direct electrical stimulation (6). We used intraoperative electromyographic recording and high intensity bipolar current pulses $(6,33)$ in 21 patients presenting with a severe motor deficit. With these valuable adjuncts the sensitivity of ESM for motor mapping was $94.4 \%$ in our hands, if we exclude from analysis those two patients whose AMP was not included into the craniotomy and take into account the patient with left hemiparesis after intraoperative lesion of his pyramidal pathways.

In a near future the improvement in sensitivity and specificity of the techniques of functional mapping provided by emerging technologies applied for localizing cognitive functions preoperatively and non invasively will likely foster these techniques to take the place of more invasive mapping methods. They include transcranial magnetic stimulation, magnetoencephalography, PET, fMRI and diffusion-weighted MRI. The ultimate goal of applying preoperative imaging techniques to the surgical treatment of lesions in highly eloquent areas is to replace more invasive intraoperative mapping procedures, but at present these techniques have an insufficient spatial resolution, too imprecise to use them as the only method of locating functional sites (35).

\section{CONCLUSIONS}

ESM for language and motor mapping represents an accurate and reliable technique, which enables resection of lesions in eloquent brain regions with surgical permanent morbidity comparable to that for lesions in non-eloquent areas. This technique is currently the most precise among established invasive mapping techniques and has greatly contributed to elucidate the functions of the nervous system. Its more recent application is to refine and validate preoperative, non-invasive mapping methods, which is the aim of our group, in line with others involved in the field of functional brain mapping.

\section{Abbreviations}

ESM - electrical stimulation mapping

MRI - magnetic resonance imaging

HGG - high grade glioma

LGG - low grade glioma

PVC - Procarbazine, Lomustine, Vincristine chemotherapy

$$
\begin{aligned}
& \text { msec - millisecond } \\
& \text { Hz - Hertz } \\
& \text { EcoG - electrocorticography } \\
& \text { DO-80 - Oral denomination test } \\
& \text { KPS - Karnofsky performance scale } \\
& \text { GTR - gross total removal } \\
& \text { SR - subtotal removal } \\
& \text { PR - partial removal }
\end{aligned}
$$




\title{
Sažetak
}

\section{HIRURGIJA TUMORA ODGOVORAJUĆIH DELOVA MOZGA: ISKUSTVO DVE INSTITUCIJE}

\author{
Signorelli Francesco, ${ }^{1,3}$ Maduri Rodolfo, ${ }^{4}$ Chirchiglia Domenico, ${ }^{2}$ Guyotat Jacques ${ }^{3}$ \\ ${ }^{1}$ Department of Experimental and Clinical Medicine, ,Magna GrFcia“ University, Catanzaro, Italy \\ ${ }^{2}$ Department of Medical and Surgical Sciences, „Magna GrFcia“ University, Catanzaro, Italy \\ ${ }^{3}$ Hospices Civils de Lyon, Service de Neurochirurgie D, \\ Hôpital Neurologique et Neurochirurgical Pierre Wertheimer, Lyon, France \\ ${ }^{4}$ Centre Hospitalier Universitaire Vaudois, Service de Neurochirurgie, Lausanne, Switzerland
}

Uvod: Hirurgija tumora odgovarajućih regija predstavlja veliki izazov, a upotreba električnog kortiko-subkortikalnog stimulacionog mapiranja (ESM) omogućava lokalizaciju senzorimotornih i govornih područja i puteva. Naš cilj je da se istaknu metodološka pitanja ESM-a i njegov uticaj na ishod prospektivne analize dve serije, iz dve institucije, sa dužim praćenjem 159 pacijenata sa lezijama odgovarajućih područja.

Materijal i metode: Svi pacijenti operisani zbog lezija odgovarajućih područja, između maja 2000. i maja 2010. godine, na neurohirurškom Odeljenju neurološke i neurohirurške bolnice "P.Wertheimer" u Lionu (Francuska) i neurohirurškom Odeljenju Univerzitetske bolnice u Katanzaru (Italija), su prospektivno uključeni u našu studiju.

Rezultati: Od 159 pacijenata, kod 141 je izvršeno hirurško uklanjanje lezija uz pomoć električnog kortiko-subkortikalnog stimulacionog mapiranja integrisanog u cilju otkrivanja intraoperativne lokalizacije anatomskih obeležja odgovarajućih područja.

Što se tiče preostalih pacijenata, kod 18 ESM se nije smatralo korisnim ili izvodljivim: kod 15 pacijenata je urađena biopsija, a kod 3 pacijenta uklonjen je tumor pod opštom anestezijom. Kod pacijenata operi-

\section{REFERENCES}

1. Uematsu S, Lesser R, Fisher RS, et al. Motor and sensory cortex in humans: topography studied with chronic subdural stimulation. Neurosurgery. 1992; 31(1): 59-71; discussion 71-2.

2. Skirboll SS, Ojemann GA, Berger MS, Lettich E, Winn HR. Functional Cortex and Subcortical White Matter Located within Gliomas. Neurosurgery. 1996; 38(4): 678-84.

3. Wunderlich G, Knorr U, Herzog H, Kiwit JC, Freund HJ, Seitz RJ. Precentral glioma location determines the displacement of cortical hand representation. Neurosurgery. 1998; 42(1): 18-26; discussion 26-7.

4. Bittar RG, Olivier A, Sadikot AF, Andermann F, Reutens DC. Cortical motor and somatosensory representation: effect of cerebral lesions. Journal of Neurosurgery. 2000; 92(2): $242-8$.

5. Duffau H. New concepts in surgery of WHO grade II gliomas: functional brain mapping, connectionism and plasticity: a review. J Neurooncol. 2006; 79(1): 77-115. sanih uz pomoć ESM-a, bilo je moguće postići kompletno uklanjanje lezija u 67,4\% slučajeva (95 pacijenata). Jedan pacijent je preminuo u neposrednom post-operativnom periodu od plućne embolije. U ukupnom periodu praćenja od 62,8 meseci, 78 pacijenata su bili živi, od kojih je 62 bilo bez recidiva uz KPS od 70\% ili više, dok je kod ostalih 80 pacijenata srednje vreme preživljavanja bilo od 23.9 meseci, sa ukupnim periodom preživljavanja (KPS $\geq 70$ ) od 21.6 meseci.

Diskusija i zaključci: Intraoperativno električno mapiranje govornih i motornih područja, kada je izvodljivo i indikovano, omogućava lokalizovanje odgovarajuće kortikalne regije i sub-kortikalnih puteva i omogućava postavljanje granica resekcije tumora prema funkcionalnim ograničenjima, uz povoljan uticaj na preživljavanje i kvalitet života. Integracija neuro-funkcionalnih podataka sa anatomskim obeležjima je i više nego korisna za ubrzavanje hirurške procedure i poboljšanje specifičnosti i osetljivosti funkcionalnog mapiranja.

Ključne reči: električno stimulaciono mapiranje, funkcionalno mapiranje, hirurgija u budnom stanju, elokventna područja, supratentorijalni tumori, gliomi, obim resekcije.

6. Signorelli F, Guyotat J, Schneider F, Isnard J, Bret P. Technical refinements for validating functional MRI-based neuronavigation data by electrical stimulation during cortical language mapping. Minim Invasive Neurosurg. 2003; 46(5): $265-8$.

7. Petrovich N, Holodny AI, Tabar V, et al. Discordance between functional magnetic resonance imaging during silent speech tasks and intraoperative speech arrest. Journal of Neurosurgery. 2005; 103(2): 267-74.

8. Lehéricy S, Duffau H, Cornu P, et al. Correspondence between functional magnetic resonance imaging somatotopy and individual brain anatomy of the central region: comparison with intraoperative stimulation in patients with brain tumors. Journal of Neurosurgery. 2000; 92(4): 589-98.

9. Liégeois F, Connelly A, Salmond CH, Gadian DG, Vargha-Khadem F, Baldeweg T. A direct test for lateralization of language activation using fMRI: comparison with invasive assessments in children with epilepsy. Neuroimage. 2002; 17(4): 1861-7. 
10. Calancie B, Nordin M, Wallin U, Hagbarth KE, Motor-unit responses in human wrist flexor and extensor muscles to transcranial cortical stimuli. Journal of Neurophysiology. 1987; 58(5): 1168-85.

11. Signorelli F, Ruggeri F, Iofrida G, et al. Indications and limits of intraoperative cortico-subcortical mapping in brain tumor surgery: an analysis of 101 consecutive cases. J Neurosurg Sci. 2007; 51(3): 113-27.

12. Keles GE, Lundin DA, Lamborn KR, Chang EF, Berger MS, Intraoperative subcortical stimulation mapping for hemispheric perirolandic gliomas located within or adjacent to the descending motor pathways: evaluation of morbidity and assessment of functional outcome in 294 patients. Journal of Neurosurgery Publishing Group. 2009; 100(3): 369-75.

13. Duffau H. Recovery from complete hemiplegia following resection of a retrocentral metastasis: the prognostic value of intraoperative cortical stimulation. Journal of Neurosurgery. 2001; 95(6): 1050-2.

14. Yingling CD, Ojemann S, Dodson B, Harrington MJ, Berger MS.Identification of motor pathways during tumor surgery facilitated by multichannel electromyographic recording. Journal of Neurosurgery Publishing Group; 2009 May 13; 91(6): 922-7.

15. Louis DN, Ohgaki H, Wiestler OD, Cavenee WK, Burger PC, Jouvet A, et al. The 2007 WHO Classification of Tumours of the Central Nervous System. Acta Neuropathol. 2007; 114(2): 97-109.

16. Scerrati M, Roselli R, Iacoangeli M, Pompucci A, Rossi GF. Prognostic factors in low grade (WHO grade II) gliomas of the cerebral hemispheres: the role of surgery. J Neurol Neurosurg Psychiatr. 1996; 61(3): 291-6.

17. Keles GE, Anderson B, Berger MS. The effect of extent of resection on time to tumor progression and survival in patients with glioblastoma multiforme of the cerebral hemisphere. Surg Neurol. 1999; 52(4): 371-9.

18. Berger MS, Deliganis AV, Dobbins J, Keles GE. The effect of extent of resection on recurrence in patients with low grade cerebral hemisphere gliomas. Cancer. 1994; 74(6): 1784-91.

19. Berger MS, Rostomily RC. Low grade gliomas: Functional mapping resection strategies, extent of resection, and outcome. J Neurooncol. 1997; 34(1): 85-101.

20. Sanai N, Berger MS. Glioma extent of resection and its impact on patient outcome. Neurosurgery. 2008; 62(4): 753-64.

21. Kamada K, Sawamura Y, Takeuchi F, et al. Expressive and receptive language areas determined by a non invasive reliable method using functional magnetic resonance imaging and magnetoencephalography. Neurosurgery. 2007; 60(2): 296-306.

22. Duffau H, Capelle L, Denvil D, et al. Usefulness of intraoperative electrical subcortical mapping during surgery for low-grade gliomas located within eloquent brain regions: functional results in a consecutive series of 103 patients. Journal of Neurosurgery. 2003; 98(4): 764-78.
23. Duffau H, Lopes M, Arthuis F, et al. Contribution of intraoperative electrical stimulations in surgery of low grade gliomas: a comparative study between two series without (1985-96) and with (1996-2003) functional mapping in the same institution. J Neurol Neurosurg Psychiatr. 2005; 76(6): 845-51.

24. Bello L, Gallucci M, Fava M, et al. Intraoperative subcortical language tract mapping guides surgical removal of gliomas involving speech areas. Neurosurgery. 2007; 60(1): 67-82.

25 . Berger MS, Hadjipanayis CG. Surgery of intrinsic cerebral tumors. Neurosurgery. 2007; 61(1 Suppl): 279-304; discussion 304-5.

26. Duffau H, Peggy Gatignol ST, Mandonnet E, Capelle L, Taillandier L. Intraoperative subcortical stimulation mapping of language pathways in a consecutive series of 115 patients with Grade II glioma in the left dominant hemisphere. Journal of Neurosurgery. 2008; 109(3): 461-71.

27. Szelényi A, Bello L, Duffau H, et al. Intraoperative electrical stimulation in awake craniotomy: methodological aspects of current practice. American Association of Neurological Surgeons; 2010; 28(2):E7.

28. Stummer W, Reulen H-J, Meinel T, et al. Extent of resection and survival in glioblastoma multiforme: identification of and adjustment for bias. Neurosurgery. 2008; 62(3): 564-76; discussion 564-76.

29. van Veelen ML, Avezaat CJ, Kros JM, van Putten W, Vecht C. Supratentorial low grade astrocytoma: prognostic factors, dedifferentiation, and the issue of early versus late surgery. J Neurol Neurosurg Psychiatr. 1998; 64(5): 581-7.

30. Chang EF, Potts MB, Keles GE, et al. Seizure characteristics and control following resection in 332 patients with low-grade gliomas. Journal of Neurosurgery. 2008; 108(2): 227-35.

31. Bizzi A, Blasi V, Falini A, et al. Presurgical functional MR imaging of language and motor functions: validation with intraoperative electrocortical mapping. Radiology. 2008; 248(2): 579-89.

32. Burchiel KJ, Clarke H, Ojemann GA, Dacey RG, Winn HR. Use of stimulation mapping and corticography in the excision of arteriovenous malformations in sensorimotor and language-related neocortex. Neurosurgery. 1989; 24(3): 322-7.

33. Yingling CD, Ojemann S, Dodson B, Harrington MJ, Berger MS. Identification of motor pathways during tumor surgery facilitated by multichannel electromyographic recording. Journal of Neurosurgery Publishing Group. 2009; 91(6): 922-7.

34. Taylor MD, Bernstein M. Awake craniotomy with brain mapping as the routine surgical approach to treating patients with supratentorial intraaxial tumors: a prospective trial of 200 cases. Journal of Neurosurgery. 1999; 90(1): 35-41.

35. Roux F-E, Boulanouar K, Lotterie J-A, Mejdoubi M, LeSage JP, Berry I. Language functional magnetic resonance imaging in preoperative assessment of language areas: correlation with direct cortical stimulation. Neurosurgery. 2003; 52(6): 1335-45; discussion 1345-7.

\section{Correspondence to/Autor za korespondenciju}

Francesco Signorelli, MD

Institutional address:

Service de Neurochirurgie D, HôpitalNeurologique et Neurochirurgical Pierre Wertheimer, 59 Boulevard Pinel, BP Lyon-Monchat, 69394 LYON Cedex 03,

France

Fax : +33 472357844

Email: signorelli2007@gmail.com 